\title{
FROM DRIVING TO DRUGS: GOVERNMENTAL REGULATION OF PREGNANT WOMEN'S LIVES
}

AFTER WEBSTER

\section{DAWn JOHNSEN $†$}

\section{INTRODUCTION}

The United States Supreme Court's July 3, 1989 decision in Webster v. Reproductive Health Services, ${ }^{1}$ generated increased debate in the courts, the press, and the legislatures about not only the right of women to choose to have an abortion, but also about the related, more general issue whether the law should ever recognize the fetus as an entity separate from the woman carrying it. The Missouri law challenged in Webster sought not only to restrict a woman's exercise of her right to make her own decisions concerning abortion, but also to define life and legal "personhood" as beginning at conception. Fueled by the Webster Court's decision to uphold both the Missouri law's sweeping definition of legal personhood and its substantive abortion restrictions, as well as by the general controversy surrounding abortion, the need to appropriately define the fetus' legal status has become critical in other contexts as well. Each day's newspapers report criminal prosecutions of women for allegedly causing harm to their fetuses through their actions while pregnant-from driving while intoxicated to failing to follow their doctors' orders concerning the abuse of illegal substances; ${ }^{2}$ women are jailed during and after pregnancy for behavior determined by the government to be against the interests of their fetuses; ${ }^{3}$ recently, the Webster decision touched even the legal status of frozen embryos in Tennessee. ${ }^{4}$

† Legal Director, National Abortion Rights Action League. B.A. 1983; J.D. 1986, Yale University. I would like to thank for their valuable suggestions on this article, Walter Dellinger, Kyra Kazantzis, Lois Murphy, Randolph Moss, Lisa Swanson, Marcy Wilder, Claudia Worrell, and especially Catherine Bell Fleming, who also provided important research, and Gene Sperling, for his tremendous assistance throughout the writing of this article.

1109 S. Ct. 3040 (1989).

2 See, e.g., Fetal Endangerment Cases Increase, Christian Sci. Monitor, Oct. 10, 1989, at 8; Keeping Baby Safe From Mom, Nat'l L.J., Oct. 3, 1988, at 1.

3 See, e.g., A Matter of Conscience, Nat'l L.J., Nov. 7, 1988, at 13; Jailed Because She is Pregnant: A Superior Court Judge Went Beyond His Duty, Wash. Post, Aug. 21, 1988, at C8.

4 See Davis v. Davis, No. E-14496, slip op. at 17-18 (Tenn. App., Sept. 21, 1989) (holding in divorce case that frozen embryos are "incipient persons" entitled to legal 
The Missouri law's sweeping declaration that the fetus is a person under Missouri law, ${ }^{5}$ (and the position of opponents of abortion that life begins at conception) blurs the subtle issues at the heart of this debate. As one reporter wrote, "[i]nevitably, the dilemma of pregnant drug users becomes part of the national abortion argument, with pro-choice forces contending that recognition of fetal rights diminishes women's rights, and anti-abortionists insisting that the unborn child deserves protection."6 The Webster Court's approval of the Missouri declaration of fetal personhood increases the danger that these important social problems will be resolved oversimplistically and without concern for and recognition of women's fundamental rights.

The fetus is a physical part of a woman. This essential fact leads both to limitations and possibilities for the government's ability to promote its interest in improving the health of newborns by affecting fetal development. The law's treatment of the fetus has far-reaching implications for women's legal status: allowing the government to impose special penalties and restrictions on pregnant women's actions in order to promote asserted interests in the fetus would, if unchecked, enable the government virtually to dictate how pregnant women must live their lives. Yet legal conflicts are not inherent in the relationship between the pregnant woman and the fetus she carries. The law also can recognize and build upon the desired future child. Before allowing the imposition of restrictions on pregnant women's behavior that are not imposed generally on others, courts should strictly scrutinize the special burdens in order to ensure that they actually further the government's interest and do not unnecessarily infringe on women's liberty.

\section{The Missouri Declaration That Life Begins At Conception}

The clause of the Missouri law most obviously hostile to women's reproductive rights is the law's opening declaration that "[t]he life of each human being begins at conception."7 That provision continues with the statement that " $[u]$ nborn children have pro-

protection, custody of which should be awarded according to the best interests of the child standard, and noting that "the recent Webster case leaves upon the door for a state to establish its compelling interest in protecting even potential human life").

5 See Mo. Rev. STAT. $\$ 1.205$ (1986).

6 Pregnant Addicts: Drug Babies Push Issue of Fetal Rights, L.A. Times, Apr. 25, 1989 at 1 , col. 3 .

7 Mo. Rev. STat. § 1.205.1(1) (1986). 
tectable interests in life, health, and well-being"8 and that Missouri laws must be interpreted to provide fetuses with "all the rights, privileges, and immunities available to other persons, citizens, and residents of this state."9

The breadth of this sweeping creation of fetal rights allows for no consideration of the different governmental purposes that might motivate fetal recognition in different contexts or of the most effective means of furthering each of the relevant government purposes. Nor does the declaration invoke the least intrusive way of furthering those interests in light of the fundamental rights of women that are at stake. Rather, it casts aside women's individual rights in pursuit of some undefined notion of fetal rights with far-reaching and largely unforeseen results.

\section{A. The Webster Court's Interpretation of the Declaration}

When coupled with operative statutory provisions, the declaration's expansive language conflicts dramatically with a woman's right to choose to have an abortion; in fact, the Missouri legislature enacted this provision as part of a comprehensive statute that places numerous restrictions on abortion. ${ }^{10}$ Nevertheless, Chief Justice Rehnquist, writing on this issue for a majority of five Justices, found that the declaration could be construed as merely expressing a value judgment favoring childbirth over abortion and as such having no

8 Id. at $\$ 1.205 .1(2)$.

9 Id. at $\S 1.205 .2$. [hereinafter, this section of the Missouri statute shall be referred to as the declaration].

10 In addition to the declaration, the Court in Webster was asked to determine the constitutionality of several other restrictions on abortion contained in Mo. REv. STAT. $\S 188$ (1986). A majority of the Court upheld $\S 188.215$ 's prohibition on the use of public facilities (broadly defined) in the performance of abortions, even in cases which do not involve the expenditure of any public funds. See Webster, $109 \mathrm{~S}$. Ct. at 3050-53. The Court also upheld $\S 188.029$ 's requirement that before a physician performs an abortion on a woman the physician "has reason to believe" is twenty or more weeks pregnant, the physician must determine whether the fetus is viable by performing "such medical examinations and tests as are necessary to make a finding of the gestational age, weight, and lung maturity" of the fetus. See id. at 3054-59. The Court dismissed as moot a challenge to $\S 188.205$ 's prohibition on the use of public funds "for the purpose of encouraging or counseling a woman to have an abortion not necessary to save her life." Id. at 3053.

The Supreme Court did not address $\S 188.025$ 's requirement that all abortions at or after sixteen weeks gestational age be performed in a hospital, because Missouri chose not to appeal the district court's holding that this provision is unconstitutional. See Reproductive Health Servs. v. Webster, 662 F. Supp. 407, 416-20 (W.D. Mo. 1987) (citing as controlling City of Akron v. Akron Center for Reproductive Health, 462 U.S. 416 (1983)). 
substantive effect on a woman's right to an abortion. In support of this interpretation, the Court stated that the provision "does not by its terms regulate abortion or any other aspect of appellees' medical practice." 11 The Court did not acknowledge the absurdity of interpreting the expansive language of the declaration-which by its express terms grants fetuses legal personhood under other Missouri laws-to exclude the very abortion restrictions with which it was enacted. By upholding the declaration, but leaving open the possibility of a future challenge to its constitutionality, the Court was able to avoid ruling on issues at the core of the fundamental right to privacy, most notably the extent of a woman's freedom to choose to have an abortion. ${ }^{12}$

The four dissenting Justices would have invalidated the declaration as conflicting with women's right to make their own decisions concerning abortion. The dissenters noted that because the law defines life as beginning at conception and conception as occurring at the time of fertilization rather than implantation, ${ }^{13}$ it interferes with more than the right to choose to have an abortion. Additionally, the declaration, in combination with the operative restrictions in the statute, restricts a woman's right to use methods of contraceptives that can prevent implantation of the fertilized ovum during the six to seven days after fertilization has occurred: the IUD, the "morning after" pill, low-dosage oral contraceptives, and the French-produced drug RU-486. The state of Missouri claimed that the declaration did not reach the use of contraceptives that operate postfertilization, but presented little support for its position. The Court

11 Webster, 109 S. Ct. at 3050. The United States Court of Appeals for the Eighth Circuit had held that because the Missouri declaration was enacted as part of a statute regulating abortion, "[ $t]$ he only plausible inference" was that "the state intended its abortion regulations to be understood against the backdrop of its theory of life." Reproductive Health Services v. Webster, 851 F.2d 1071, 1076 (8th Cir. 1988). In so ruling, the Court of Appeals relied on the Supreme Court's statement in Roe v. Wade, 410 U.S. 113 (1973), that "a State may not adopt one theory of when life begins to justify its regulation of abortions." Reproductive Health Services, 851 F.2d at 1075-76 (quoting Akron, 462 U.S. at 444, citing Roe, 410 U.S. 113, 159-62).

12 Although four Justices expressed disagreement with the holding in Roe, Justice O'Connor provided the fifth and critical vote for upholding two of the abortion restrictions, and she relied on relatively narrow grounds framed in a manner that avoided reconsideration of the standards for protecting the right to choose abortion. See Webster, 109 S. Ct. at 3060-61.

13 This is contrary to the accepted medical definition of conception. The American College of Obstetricians and Gynecologists defines conception as "the implantation of the blastocyst [fertilized ovum]." Obstetric Gynecolocic Terminology 229, 327 (E. Hughes ed. 1972). 
dismissed this problematic implication-with virtually no analysisas an uncertain application of the provision. ${ }^{14}$

\section{B. Other Applications of the Declaration}

In rejecting the facial challenge to the Missouri declaration as restrictive of access to abortion and contraceptives, the Supreme Court suggested that Missouri state courts might interpret the declaration's substantive impact as limited to protections already afforded fetuses by state tort and probate law. Such an interpretation, however, could conflict with the declaration's express directive that, subject only to constitutional constraints, other state laws must be interpreted to provide fetuses "all the rights, privileges, and immunities available to other persons, citizens, and residents of the state."15 The Court did acknowledge that the declaration might be interpreted to have some substantive effect beyond existing recognition of the fetus under state tort and probate law. Yet the Court deferred

14 The potential impact of the declaration on contraceptive use was discussed not only in several of the briefs but also during the oral argument in Webster:

Justice Scalia: I don't see why a court that can draw that line [between the first, second and third trimesters] can't separate abortion from birth control quite readily.

Mr. Susman: If I may suggest the reasons in response to your question, Justice Scalia. The most common forms of what we generically in common parlance call contraception today, IUD's, low-dose birth control pills, which are the safest type of birth control pills available, act as abortifacients. They are correctly labeled as both.

Under this statute, which defines fertilization as the point of beginning, those forms of contraception are also abortifacients. Science and medicine refers to them as both. We are not still dealing with the common barrier methods of Griswold. We are no longer just talking about condoms and diaphragms.

Things have changed. The bright line, if there ever was one, has now been extinguished. That's why I suggest to this Court that we need to deal with one right, the right to procreate. We are no longer talking about two rights.

Transcript of Arguments Before Court on Abortion Case, N.Y. Times, Apr. 27, 1989, at B12, B13, col. 2.

Justice Stevens: But the preamble would make your prohibition against abortions in public facilities apply to things like installing an IUD and that sort of thing.

Mr. Webster: Your Honor, we would contend that is not the case. We believe it would take an additional specific statutory enactment by the Missouri General Assembly to do that. The only language we have now found in Chapter 188 is silent as to abortions before viability, and we certainly wouldn't construe that the preamble alone -

Correction: Transcription In Abortion Argument, N.Y. Times, Apr. 28, 1989, at B8, col. 5. 15 Mo. Rev. STAT. $§ 1.205 .2$ (1986). 
consideration of the constitutionality of the declaration until a future challenge to a specific attempted application of the provision:

We think the extent to which the preamble's language might be used to interpret other state statutes or regulations is something that only the courts of Missouri can definitively decide. . . . It will be time enough for federal courts to address the meaning of the [declaration] should it be applied to restrict the activities of appellees in some concrete way. ${ }^{16}$

Already, in the few months since the Webster decision, the sweeping and indiscriminate declaration has been applied in bizarre ways, demonstrating the far-reaching and often unforeseen consequences of a broad law creating fetal personhood. For instance, two Missouri courts applied the provision in a manner directly harmful to abortion providers and women requiring their services. Two judges acquitted a total of twenty-five people of charges of criminal trespass in connection with anti-abortion protests at abortion clinics. ${ }^{17}$ The judges accepted the protestors' defense that their criminal actions were necessary to stop a greater evil, the taking of unborn "lives." Noting the Supreme Court's refusal in Webster to invalidate the Missouri declaration, the judges found that the declaration supported the protestors' use of the necessity defense. ${ }^{18}$ As one judge stated, under the declaration "an unborn child is a person entitled to all the rights ... possessed by a born child" and "violations [of trespassing laws] were necessary as emergency measures to avoid the . . . death and maiming of unborn children." 19 This interpretation of the Missouri law could thus be used to legitimize protestors' violent destruction of a clinics' medical equipment, or even a clinic itself. ${ }^{20}$ The St. Louis

16 Webster, $109 \mathrm{~S}$. Ct. at 3050.

17 See Abortion Protesters Acquitted in City, St. Louis Post-Dispatch, Aug. 25, 1989, at 1; Twenty-one Abortion Protestors Acquitted of Trespassing, Wash. Times, Aug. 17, 1989, at 5; Abortion Foes Exonerated in St. Louis, Kansas City Times, Aug. 17, 1989, at 1; Abortion Protesters Acquitted - 'Necessity Defense' Scores First Victory, St. Louis Post-Dispatch, Aug. 17,1989 , at 1 . This issue is currently before the Michigan Court of Appeals in a case in which the lower court rejected the necessity defense and sentenced a woman to 75 days in jail for criminal trespass. See Anti-Abortion Appeal Uses 'Necessity' Issue, St. Louis Post-Dispatch, Oct. 17, 1989, at 1.

18 These rulings conflict directly with the Supreme Court's recognition of women's right to choose to have abortions. As discussed above, the Webster majority ruled only that it would not consider the declaration's constitutionality until a state court had interpreted the statute's scope or the provision had been applied in a detrimental fashion. See supra text accompanying notes 17-18.

19 Abortion Protestors Acquitted, supra note 17.

20 Between the years 1977 and 1987, there were 712 reported acts of violence against abortion providers including bombings, arson, hostage-taking, burglary, vandalism and death threats. Between January of 1987 and August 15, 1989, there 
Circuit Attorney commented, "[t]he next thing these people are going to do is start killing guards at these buildings and claiming that they have a right to do it."21

The Missouri declaration was also cited by a twenty-year-old man charged with driving while intoxicated and possession of alcohol by a minor. The man faced losing his driver's license under a state law that mandates the loss of a license for anyone under 21 who is convicted of driving while intoxicated. ${ }^{22}$ The man claimed that the law did not apply to him, however, arguing that he had reached the age of 21 under Missouri law because the declaration adds nine months of gestation to his life. ${ }^{23}$

A lawyer representing a pregnant woman who is currently serving a three-year prison sentence for forgery and theft cited the declaration in a suit filed on behalf of the woman's fetus. ${ }^{24}$ The suit contends that by incarcerating the woman, the state is unconstitutionally imprisoning the fetus because the fetus was not first "charged with a crime, allowed an attorney, convicted or sentenced." The suit also alleges that the fetus was "denied adequate diet, medical care and 'the opportunity to develop into a healthy live born child because of conditions at the prison.." 25 The fetus' lawyer stated, "If life begins at conception, then fetuses are supposed to be like anyone else - They're a person [sic] and they have constitutional rights." 26 Under this reasoning, pregnant women could never be jailed for

were 21,742 arrests of persons blockading abortion clinics. See National Abortion Federation, Incidents of VIolence and Disruption Against Abortion Providers 1989.

21 See Abortion Protestors Acquitted in City, supra note 17. The Model Penal Code commentaries suggest that the necessity defense is available where a person kills one person in order to save the lives of two or more people. See Model Penal Code $\S 3.02$ comment (Tentative Draft No. 8, 1958).

22 See Abortion Protesters Acquitted in City, supra note 17.

23 See id.

24 The attorney in this case apparently was motivated by the important goal of ensuring that the woman would obtain adequate care during her pregnancy: he also filed a companion suit on behalf of the woman alleging that the prison was violating her constitutional rights "by failing to provide her with a proper diet, medical care, exercise and a safe environment in which to carry the fetus." The attorney was quoted as saying, "I'm not pro-choice or pro-life or any of that stuff. But I think there's some problems [sic] with the law and the courts are eventually going to have to rule on it." Fetus Illegally Jailed, Suit Says, Arkansas Democrat, Aug 4, 1989, at 9A. This second lawsuit is obviously the preferable approach for the law to take because it is aimed at remedying the actual harm: the prison's alleged failure to provide adequate prenatal care for the pregnant woman, and not the imprisonment of a fetus without affording it due process.

$25 I d$.

2(i Fetus Illegally Jailed, Inmate's Lawyer Argues, Wash. Times, Aug. 4, 1989 at 4. 
committing any crime, given the that fetuses are incapable of committing crimes and thus should not be imprisoned along with women. ${ }^{27}$

\section{From Recognition Under Tort And Probate Law To The Creation of Maternal-Fetal Conflicts}

The Supreme Court's interpretation of the declaration as potentially limited to existing protections under state tort and probate law ignores not only the express language of the declaration, but also crucial distinctions between the limited purposes served by fetal recognition under tort and probate laws and the broad purpose behind the Missouri declaration. Historically, American law did not recognize the fetus as a legal entity distinct from the pregnant woman carrying it. Legal recognition of the fetus first occurred in narrow, specifically identified contexts under tort and probate law to advance specific purposes that do not depend on a particular moral view of the fetus' value and do not create legal conflicts with pregnant women. ${ }^{28}$

These initial laws did not in any sense create independent "fetal rights," but were aimed at protecting the interests of people, including pregnant women; in certain circumstances this required the law to acknowledge the existence of the fetus before birth. For example, the legal fiction of considering a fetus to be a person if a child is subsequently born alive was first adopted for the purposes of inheritance law. This fiction respects the presumed desire of a deceased man to provide for a child conceived by him but not yet born at the

27 As a result of the legal confusion caused by the declaration, two Missouri state legislators have submitted requests to Missouri Attorney General William Webster, who argued the Webster case for Missouri, for opinions about the legal effect of the provision. Specifically, the legislators have asked for opinions as to the effect of the definition of life beginning at conception on the legal age to sign contracts, vote, marry, obtain a driver's license, serve or be served alcoholic beverages, drop out of school, be segregated from adult prisoners, be under the jurisdiction of juvenile court, inherit money or property, and receive benefits under insurance policies. A legislator also stated that she plans to request an attorney general opinion about whether two Missouri courts were correct in ruling that the declaration supports a necessity defense for anti-choice protestors accused of trespassing at clinics where abortions are performed. See Webster's Views Sought on Use of Abortion Law, St. Louis Post-Dispatch, Sept. 6, 1989, at 1 .

28 For a more extensive discussion of the history of the development of the legal status of the fetus, see Note, The Creation of Fetal Rights: Conflicts with Women's Constitutional Rights to Liberly, Privacy, and Equal Protection, 95 YALE L.J. 599, 600-13 (1986) (authored by Dawn Johnsen). 
time of his death. ${ }^{29}$ Similarly, in 1946 a court first recognized a child's cause of action for injuries inflicted upon a pregnant woman where the injuries interfered with the development of a viable fetus and resulted in the child suffering after birth from the effects of the prenatally inflicted harm. ${ }^{30}$

Until recently, the law applied these forms of fetal recognition were applied solely in ways consistent with and supportive of the interests of pregnant women, including their interest in reproductive autonomy. Because the fetus is a physical part of a woman, third parties can tortiously harm fetal development only by physically assaulting or battering a pregnant woman. The threat of legal action deters such tortious acts and therefore directly benefits pregnant women as their future children. Moreover, allowing a child's parents to sue and recover damages on behalf of the child may enable the parents to meet the added expenses associated with the child's injuries. Many states subsequently went beyond this cause of action to allow recovery against third parties for causing a woman's pregnancy to terminate without her consent; this protects pregnant women from severe bodily intrusion, physical harm and the involuntary termination of wanted pregnancies. ${ }^{31}$

In sharp contrast, the declaration, by making the subjective

29 See, e.g., Medlock v. Brown, 163 Ga. 520, 136 S.E. 551 (1927); McLain v. Howald, 120 Mich. 274, 79 N.W. 182 (1899); Cowles v. Cowles, 56 Conn. 240, 13 A. 414 (1887); see also Christian v. Carter, 193 N.C. 537, 538, 137 S.E. 596, 597 (1927) (stating that the civil law rule as to the recognition of fetuses "apparently was based upon the presumed oversight or inadvertence of the parent in providing for an existing or a contingent situation"). Even within property law, recognition of the fetus is the exception rather than the rule. See, e.g., In re Peabody, 5 N.Y.2d 541, 158 N.E.2d 841, 186 N.Y.S.2d 265 (1959) (holding that a fetus was not a person "beneficially interested" for purposes of $\S 23$ of New York Personal Property Law and distinguishing the distinctive purposes served by the "fiction" of considering a fetus subsequently born alive a person for certain other matters of property law).

30 See Bonbrest v. Kotz, 65 F. Supp. 138, 140 (D.D.C. 1946) (first case to recognize a cause of action by a child for injuries received in utero after viability).

31 In some cases, state courts have stated explicitly that the purpose behind recognizing this cause of action is to compensate parents. See Volk v. Baldazo, 103 Idaho 570, 574, 651 P.2d 11, 15 (1982) ("[T]he wrongful death statute confers upon parents a cause of action for the wrongful death of a 'child' and thus protects the rights and interests of the parents, and not those of the decedent child"); Dunn v. Rose Way, Inc., 333 N.W.2d 830,832-33 (Iowa 1983) (distinguishing between claim by estate of fetus under state's survival statute in which "the wrong is done to the injured person and to that persons's estate," and a claim by parents for loss of a fetus under a wrongful death statute in which "the wrong is done to a child's parents," and concluding that the wrongful death statute, "involved ... a right of recovery given to a parent. The parent's loss does not depend on the legal status of the child"). Other state courts, however, have relied on a general state interest in protecting life. See 
value judgment that life begins at conception, confers upon the fetus qua the fetus sweeping rights, privileges, and immunities of personhood guaranteed under Missouri law that are capable of completely overriding the rights of women in a variety of contexts. The declaration was enacted as part of a statute designed to interfere with a woman's ability to exercise the right to choose to have an abortion. The declaration thus creates a legal regime centered on creating conflict between a woman and the fetus she carries. Despite the Webster majority's misleading reference to tort and probate law, the declaration's attempt to create fetal personhood reflects a far different purpose, with far more ominous implications for pregnant women: to protect the fetus qua fetus in a wide range of undelineated contexts.

Ironically, the Supreme Court's decision in Roe v. Wade ${ }^{32}$ is also partly responsible for recent deviations in the legal treatment of the fetus. The Court in Roe held that after the point of fetal viability (at which point the fetus is able to survive outside the womb) the government has a compelling interest in the potential life of the fetus that justifies prohibiting a woman from intentionally aborting the fetus. ${ }^{33}$ The Court permitted states to interfere with the rights of pregnant women contemplating abortion in order to promote an adverse interest asserted by the state in protecting the potential life of the viable fetus. Although the direct impact on women's rights is minimal because few women choose to have abortions late in pregnancy, and those that do have the most compelling of reasons, the decision set a dangerous precedent by recognizing a governmental interest in the fetus that is not contingent on live birth and is not aimed at protecting the interests of women or children.

Nonetheless, the Court in Roe created only a narrow exception to the general rule of individual reproductive autonomy and held more generally that the fundamental right to privacy guarantees individuals freedom from governmental intrusion in matters concerning

Danos v. St. Pierre, 402 So. 2d 633, 639 (La. 1981) (citing legislative pronouncement that "a human being exists from the moment of fertilization and implantation").

Similarly, penalizing third parties for causing a woman's pregnancy to terminate without her consent through criminal laws can be viewed as protecting pregnant women from physical assault and serious harm. Although most states that have used the criminal law in this manner have done so by defining the fetus to be the victim of the crime, at least one state explicitly focused the law's protection on the pregnant woman, rather than the fetus. See N.M. Stat. ANN. § 30-3-7 (Supp. 1989).

32410 U.S. 113 (1973).

33 See id. at 163. 
childbearing. ${ }^{34}$ Even within the narrow exception, the government's ability to promote its interest in the fetus is constitutionally constrained: after viability, the government may prohibit abortion only if the pregnancy creates no threat to the woman's physical or mental health. ${ }^{35}$ The Roe Court expressly rejected any notion of "fetal personhood" under the United States Constitution, finding instead that "the law has [traditionally] been reluctant to endorse any theory that life ... begins before live birth" and that historically the legal rights of fetuses were limited to "narrowly-defined situations and ... [were] contingent on live birth." 36 The Roe Court's recognition of a compelling state interest in the potential life of a viable fetus does not, therefore, support the sweeping creation of "fetal rights" contemplated by the Missouri declaration.

While the Webster Court rejected the contention that the declaration affects women's rights concerning abortion or contraception, the Court failed even to note that the declaration's sweeping creation of "fetal rights" might pose the severe threats to women's liberty in other contexts. This danger is not limited to cases of fetal recognition premised on a particular valuation of the fetus qua fetus. Women's liberty is jeopardized any time the law treats the fetus as a legal entity independent of the pregnant woman, including those instances in which fetal recognition is contingent upon subsequent live birth and is therefore meant to protect the interests of children. For example, though tort actions for prenatal injuries almost invariably have been applied to further women's interests, the recognition of this cause of action can be used to subvert the rights of pregnant women. For example, one court allowed a child to sue his mother for allegedly causing him to be born with discolored teeth by using the antibiotic tetracycline during pregnancy. ${ }^{37}$

The fetus is a physical part of the pregnant woman. This fact allows the law to protect fetal development and future children by protecting women from physical injury. Yet this fact also creates the potential for extreme deprivations of women's liberty when the government asserts an interest in the fetus that is hostile to women's autonomy. When drafting the declaration, the Missouri legislature exhibited some sensitivity to this potential problem. A provision of the same statute states, "[n]othing in this section shall be interpreted as creating a cause of action against a woman for indirectly harming

34 See id. at $152-53$.

35 See id. at 163-64.

36 See id. at 161.

37 See Grodin v. Grodin, 102 Mich. App. 396, 301 N.W.2d 869 (1980). 
her unborn child by failing to properly care for herself or by failing to follow any particular program of prenatal care." Although this provision may protect women from being sued by their children for acting "negligently" during pregnancy, the declaration that life begins at conception nonetheless threatens women with other forms of government interference that is ostensibly aimed at "protecting" fetuses from the women who bear them.

Before the majority in Webster ruled that the declaration might have no or little substantive effect, a Missouri court had already applied the provision in a manner directly hostile to the rights of women. ${ }^{38}$ A state court relied on the declaration in overriding the informed medical decision of a competent pregnant woman and ordering her to submit to a cesarean section. The court found that "the life, health and well-being" of the woman's fetus "may be jeopardized" by her decision not to have the surgery. ${ }^{39}$ The Deaconess Hospital case, just as other recent instances in which the government has asserted interests in the fetus to justify overriding the decisions and interests of pregnant women, raises profound questions as to what, if any, limits the United States Constitution places on the ability of the government to treat a pregnant woman and the fetus she bears as legal adversaries, with the government defining and representing the interests of the fetus against the woman.

\section{Constitutional Limits On Governmental Assertion of FETAL INTERESTS}

Just as the Missouri declaration deviates sharply from the legal status traditionally afforded the fetus, in other isolated instances during the past decade courts have used both the civil and criminal law to impose upon women special penalties and restrictions that require them to act in the best interests of the fetuses they carry, or may carry in the future. These special restrictions on liberty have been imposed on women before, during, and after pregnancy, and have intruded upon a wide range of activities and decisions, from potentially harmful and even illegal behavior such as the use of illegal

38 The declaration was also cited by a Missouri court as evidence of a state policy favoring life in order to support its ruling preventing the withdrawal of lifesustaining treatment from a permanently comatose patient. See Cruzan v. Missouri Dep't of Health, 760 S.W.2d 408 (Mo. 1988), cert. granted, 57 U.S.L.W. 3859 (U.S. July 3, 1989) (No. 88-1503) (to be argued Dec. 6, 1988).

39 See Deaconess Hosp. v. McRoberts, No. 874-00172 (St. Louis Cir. Ct. May 21, 1987). 
drugs to socially important and valued behavior such as working, driving, and obtaining necessary medical treatment.

The government certainly can and should enforce criminal laws against pregnant women criminal laws that apply equally to the general population. Any governmental action, however, that singles out women for special penalties and restrictions solely because they are or may become pregnant should be recognized as implicating the fundamental right to privacy, which is based in the fourteenth amendment's guarantee of liberty. In particular, such governmental interference implicates two strands of the fundamental right to privacy: the right to choose to bear a child and the right to bodily integrity. ${ }^{40}$ Although not all such governmental interference with women's liberty is necessarily impermissible, all such governmental intrusion should be subject to the strict scrutiny standard of judicial review. Attempts by the government to implement its definition of women's optimal procreative role through the imposition of special restrictions constitute a tremendous intrusion on women's lives. Courts should uphold such intrusions only if the government demonstrates that it possesses a compelling interest and that this interest is furthered by means that are the least burdensome on women's fundamental rights. ${ }^{41}$

\section{A. Scope of Threatened Infringements on Women's Liberty}

In order to determine whether women's fundamental rights are threatened by a governmental attempt to dictate women's behavior based on women's reproductive capacity, it is critical to consider the nature and scope of the intrusions on women's liberty that would result if courts did not closely scrutinize the government's use of the fetus as a vehicle by which to restrict women's actions. Because the fetus is a completely dependent, physical part of a pregnant woman that can be affected only through her body, allowing the government to demand that women comport themselves in the best interests of their fetuses-as the government defines those best interests-would effectively create an adversarial relationship within the woman's own body that she could avoid only by aborting the pregnancy. Were

40 For general discussions of the constitutional issues raised by this form of fetal recognition, see Gallagher, Prenatal Invasions and Intervention: What's Wrong with Fetal Rights, 10 HaRv. Women's L.J. 9 (1987); Rhoden, The Judge in the Delivery Room: The Emergence of Court-Ordered Cesareans, 74 CALIF. L. Rev. 1951 (1986); Note, supra note 28.

11 See, e.g., San Antonio Indep. School Dist. v. Rodriguez, 411 U.S. 1, 16 (1973); Shclton v. Tucker, 364 U.S. 479, 488 (1960). 
these laws subject only to rational relationship review, the government would have a free hand to single out women for special restrictions that could amount to virtually totalitarian control of a woman's physical being and life during pregnancy. The legal fiction of "fetal personhood" masks this critical reality.

A wide range of common conditions and activities by a pregnant woman can pose some threat to fetal development, including: being overweight or underweight, working or even living in certain environments, rejecting or undergoing specific medical treatments, exercising, not exercising, failing to eat "well," failing to "stay off of her feet," smoking, drinking alcohol, ingesting caffeine, taking nonprescription, prescription, or illegal drugs, and suffering physical harm through accident or illness. ${ }^{42}$ These behaviors can affect fetal development even before a woman knows she is pregnant, as can a woman's health or behavior even prior to pregnancy. Under a law that declared legal personhood to begin at conception and allowed the government to second-guess women's decisions and actions on the basis of their effect on fetuses, any of these behaviors could provoke criminal prosecution, civil liability, incarceration, or other direct state intervention.

Some advocates of this type of government interference with women's procreative liberty have even advocated creating "a fetal right to begin life with sound body and mind" 43 or a woman's "duty to bring the child into the world as healthy as is reasonably possible."44 Defining the government's interest in terms of a right on the part of each fetus creates a legal framework with enormous potential for conflict with the rights of each pregnant woman. A right "to begin life with sound body and mind" would impose on women a legal obligation to make themselves ideal incubators throughout the nine months of pregnancy, sacrificing their obligations to their children, husbands, and jobs, as well as to themselves. The range of activities in which people typically engage on a daily basis would be severely circumscribed for pregnant women, and at least to some extent for all women. Given the tremendous problems in determining which among countless factors combined to cause, for example, a

42 These are among the activities cited as harmful to fetal development by those who advocate the expansion of special governmental regulation of pregnant women's behavior. See Note, supra note 28, at 605-09.

43 Dougherty, The Right to Begin Life with Sound Body and Mind: Fetal Patients and Conflicts With Their Mothers, 63 U. DET. L. REv. 89, 89 (1985).

44 Robertson, Procreative Liberty and The Control of Conception, Pregnancy, and Childbirth, 69 VA. L. REv. 405, 438 (1983). 
baby to be born prematurely or with low birthweight, women would risk being held legally liable for any illness or perceived imperfection in their child.

Carrying this rationale to its logical extreme, if each child had the right to be born healthy, women might have a legal duty to abort in cases of fetal deformity. One leading advocate of creating individual "fetal rights" has written that parents may have a legal obligation "to act in reasonable ways to prevent the birth of a child who would certainly or likely suffer prenatally, or to accept prenatal treatment if it is expected to benefit the would-be child." ${ }^{\text {"45 }}$ At least one court has suggested that a child could sue his or her mother for not having an abortion because there was "no sound public policy which should protect those parents from being answerable for the pain, suffering and misery which they have wrought upon their offspring."46 Even if a duty to abort were not recognized, allowing the legal system to compel pregnant women to act in the interests of fetuses without requiring the government intervention to be necessary to promote a compelling interest, would create an incentive for women to have abortions as well as to avoid pregnancy.

This "parade of horribles" is more than just a logical possibility: for some women, it has become a reality. In relatively rare, but varied and ominous instances, courts and legislatures have asserted an interest in protecting fetuses to justify infringements on pregnant women's liberty. These intrusions have taken many forms, including court-ordered medical treatment and surgery (including in one case surgery that contributed to a woman's death); ${ }^{47}$ lawsuits for prenatal injuries brought against women by their own children for not behaving like "reasonable" pregnant women (in one case, for using antibiotics during pregnancy, and in a second case, for driving negligently during pregnancy), ${ }^{48}$ criminal prosecution for "prenatal child (1984).

45 Shaw, Conditional Prospective Rights of the Fetus, 5 J. OF LEGAL MED. 63-66

46 Curlender v. Bio-Science Laboratories, 106 Cal. App. 3d 811, 829, 165 Cal. Rptr. 477, 488 (1980).

47 See Deaconess Hosp. v. McRoberts, No. 874-00172 (St. Louis Cir. Ct. May 21, 1987); In re A.C., 533 A.2d 61 1, 617 (D.C. App. 1987), vacated E' reh'g en banc granted, 539 A.2d 203 (D.C. 1988); Kolder, Gallagher \& Parsons, Court-Ordered Obstetrical Interventions, 316 N. ENG. J. MED. 1192 (1987).

48 A Michigan court created a cause of action allowing a child to sue his mother for allegedly inflicting on him prenatal injuries through her use of the antibiotic tetracycline during pregnancy. See Grodin v. Grodin, 102 Mich. App. 396, 301 N.W.2d 869 (1980). The court remanded for a determination of whether the woman's use of the antibiotic satisfied the relevant legal standard, which was that of a "reasonable" pregnant woman. See id. at 400-02, 301 N.W.2d at 870-71. An Illinois 
abuse" (for failing to follow a doctor's orders during pregnancy ${ }^{49}$ and for manslaughter (for suffering a miscarriage in a car accident while allegedly driving while intoxicated ${ }^{50}$ ); and even imprisonment solely to allow the government to control directly the woman's actions for the duration of her pregnancy. ${ }^{51}$

During the last few years, governmental attempts at imposing special restrictions on women on the basis of pregnancy have been particularly prevalent in the context of the use of controlled substances by pregnant women. Of course, pregnant women are not exempt from prosecution for disobeying laws directed against the use by any person of illegal drugs such as cocaine or heroin. Yet during the last few years, several dozen women have been subjected to criminal prosecution aimed at imposing special and additional punishments for their use of illegal substances during pregnancy, premised on the harm the women allegedly caused to the fetuses they carried. ${ }^{52}$ The first woman to be criminally convicted under this

court similarly permitted a five-year-old girl to sue her mother for allegedly causing the child to be born with a damaged intestine due to injuries her mother suffered in an automobile accident while she was pregnant. The girl alleged that her mother caused the accident by driving negligently. The Illinois Supreme Court reversed on appeal. See Stallman v. Youngquist, 52 Ill. App. 3d 683, 504 N.E.2d 920 (1st Dist. 1987), rev'd, 125 Ill. 2d 267, 531 N.E.2d 355 (1988).

49 In California, a woman was criminally prosecuted for disobeying her physician's orders by not seeking immediate medical assistance when she began bleeding vaginally, by having sexual intercourse with her husband, and by using illegal drugs during pregnancy, allegedly causing her son to be born brain-damaged. See People v. Stewart, No. M508197 (San Diego Mun. Ct. Feb. 23, 1987).

50 See DA Sees No Politics in Fetal Death Case, Boston Globe, Sep. 16, 1989, at 25 (Metro/Region).

51 See In re Steven S., 126 Cal. App. 3d 23, 31, 178 Cal. Rptr. 525, 529 (1981).

52 Jennifer Johnson, a Florida woman, was convicted in July 1989, the same month the Court decided Webster. See Mother Is Guilly of Delivering Drug In Course of Birth, Wall St. J., July 17, 1989, at B12. She was convicted under a statute that prohibited the distribution of a controlled substance to a minor and contained a penalty of up to thirty years imprisonment.

Melanie Green of Rockford, Illinois, whose baby died two days after being born with drugs in her system, in May 1989 became the first woman to be charged with manslaughter based on her alleged drug use during pregnancy. The grand jury refused to return an indictment against her. See Jury in Illinois Refuses to Charge Mother in Drug Death of Newborm, N.Y. Times, May 17, 1989, at 18.

Brenda Vaughn of Washington, D.C. pled guilty in April 1988 to forging several checks. See United States v. Vaughn, 117 Daily Wash. L. Rep. 441 (D.C. Super. Ct. Mar. 7, 1989). Rather than imposing the probation recommended by the prosecutor, the judge sentenced Ms. Vaughn to prison because she had tested positive for cocaine and the judge wanted to ensure that she would not use cocaine for the duration of her pregnancy. When Ms. Vaughn was to be released several weeks before giving birth as part of a general early release ordered to alleviate a prison overcrowding emergency, Ms. Vaughn's sentencing judge issued a special order 
type of special prosecution was convicted of delivering illegal drugs to "a minor" through her umbilical cord during childbirth.

\section{B. Judicial Responses To Threat To Women's Fundamental Liberty}

Courts have been slow to appreciate the dangers inherent in imposing these types of special penalties on women and the potential created for wide-ranging governmental intrusion in pregnant women's lives if such special penalties are not subject to strict judicial scrutiny. The Illinois Supreme Court recently became perhaps the first court to address these broader implications in a case in which it refused to allow a girl to sue her mother for allegedly causing the girl to suffer prenatal injuries. The court noted that if it held otherwise, " $[\mathrm{m}]$ other and child would be legal adversaries from the moment of conception until birth." 53 In a powerful dissent in a recent analogous case in the Title VII context, Judge Frank Easterbrook protested the Seventh Circuit's en banc decision upholding a company's exclusion of all women who had not proven themselves to be infertile from working with lead due to the potential harmful effects on fetal development. ${ }^{54}$ Judge Easterbrook noted that this type of reasoning could exclude women from more than 20 million jobs, ${ }^{55}$ and that the implications of allowing employers-rather than

exempting her from the early release to ensure that she would stay in prison until she gave birth. See id.

The prosecution and jailing of women in these initial cases were pursuant to criminal statutes and sentencing procedures that clearly were not designed for the purpose of imposing special punishment on pregnant women who use controlled substances. Since then, however, three states-Illinois, Minnesota, and Delawarehave enacted legislation specifically for the purpose of imposing such special penalties. Currently pending in the United States Senate is a bill entitled the "Child Abuse During Pregnancy Prevention Act of 1989" which would establish model projects on pregnant women and substance abuse. See S. 1444, 101 st Cong., Ist Sess. (1989) (introduced July 31,1989 ). To be eligible for a grant under the bill, a state is required to certify both that it is a crime in that state for a woman to give birth to "an infant who is addicted or otherwise injured or impaired by the substance abuse of its mother during pregnancy" and that the penalty for that crime is three years of incarceration with mandatory rehabilitation.

53 Stallman v. Youngquist, 125 Ill. 2d 267, 276, 531 N.E.2d 355, 359 (1988) (stating that the recognition of a legal right to begin life with a sound mind and body would have serious ramifications for all women and their families and for the society's view of women's reproductive abilities-such rights would make a pregnant woman a guarantor of the mental and physical health of another, a duty which has never previously been legally recognized).

54 See International Union v. Johnson Controls, 886 F2d 871, 908 (7th Cir. 1989) (Easterbrook, J., dissenting).

55 See id. at 914 (Easterbrook, J., dissenting). 
the women themselves-to weigh the risks and make the final evaluation were staggering:

How risky is a blood lead level exceeding $30 \mathrm{mg} / \mathrm{dl}$ compared with other hazards? Most comparisons show that smoking and drinking are quite dangerous to fetuses, more so than many contaminants found in the workplace. ... The hazards created by occupational chemicals span many orders of magnitude: some are safer than the sweeteners we wolf down, some are dangerous indeed. Where does lead fit on that spectrum? I cannot believe that Johnson would be entitled to fire female employees who smoke or drink during pregnancy - let alone to fire all female employees because some might smoke or drink - which makes it hard to exclude women to curtail risk from other substances.

How does the risk attributable to lead compare, say, to the risk to the next generation created by driving a taxi? A female bus or taxi driver is exposed to noxious fumes and the risk of accidents, all hazardous to a child she carries. Would it follow that taxi and bus companies can decline to hire women? That an employer could forbid pregnant employees to drive cars, because of the risk accidents pose to fetuses? For all we can tell, accepting Johnson's argument compels us to answer "yes" to these questions. . . . Excluding women from industrial jobs at Johnson may reduce risk attributable to lead at the cost of increasing other hazards. There is a strong correlation between the health of the infant and prenatal medical care; there is also a powerful link between the parents' income and infants' health, for higher income means better nutrition, among other things. Removing women from well-paying jobs (and the attendant health insurance), or denying women access to these jobs, may reduce the risk from lead while also reducing levels of medical care and the quality of nutrition. The net effect of lower income and less medical care could be a reduction in infants' prospects. $^{56}$

At least one court has found constitutional barriers exist to legal recognition of the fetus that would interfere with women's autonomy. ${ }^{57}$ A family court in New York held that a woman's prenatal

$56 \mathrm{Id}$. at 916-18 (Easterbrook, J., dissenting) (footnotes \& citations omitted).

57 Only a handful of other courts have even recognized the possibility that constitutional limits may exist, and the others all rejected the suggestion that those limits were exceeded in the cases before them. See In re A.C., 533 A.2d 611, 617 (D.C. App. 1989) (stating that in ordering a woman to submit to cesarean section, "the trial judge did not err in subordinating A.C.'s right against bodily intrusion to the interests of the unborn child and the state"), vacated E' reh'g en banc granted, 539 A.2d 203 (D.C. 1988); United States v. Vaughn, 117 Daily Wash. L. Rep. 441 (D.C. Super. Ct. Mar. 7, 1989) (summarily rejecting suggestion that "women's rights" might prevent incarceration of woman guilty of theft for duration of her pregnancy 
drug use could not alone form the basis of a finding of neglect. ${ }^{58}$ Noting that "[b]y becoming pregnant, women do not waive the constitutional protections afforded other citizens," the court stated:

[t]o carry the Law Guardian's argument to its logical extension, the State would be able to supersede a mother's custody right to her child if she smoked cigarettes during her pregnancy, or ate junk food, or did too much physical labor or did not exercise enough. The list of potential intrusions is long and constitute entirely unacceptable violations of the bodily integrity of women. ${ }^{59}$

\section{Special Burdens on Women's Liberty to Further Fetal Interests Trigger Strict Scrutiny}

The Supreme Court has long held that the Fourteenth Amendment's guarantee of liberty protects the individual substantively from government interference with those certain private matters that are crucial to self-determination. Although the Justices and constitutional scholars disagree about the precise scope of the protected fundamental rights, there is widespread consensus that this constitutional protection extends beyond those rights specifically enumerated in the Constitution and also includes at least "those fundamental liberties that are implicit in the concept of ordered liberty,' such that 'neither liberty nor justice would exist if they were sacrificed." "60

The power to promote perceived fetal interests by imposing upon women special burdens or penalties would give the government almost complete control over women's lives, and thus should be viewed as implicating the fundamental right to privacy, guaranteed by the fourteenth amendment. Such unique restrictions specifically implicate two strands of the right to privacy that the Supreme Court has recognized as fundamental and thus entitled to strict judicial scrutiny: the right to choose to bear a child and the right to bodily integrity. ${ }^{61}$

for sole purpose of preventing her use of cocaine); Jefferson v. Griffin Spalding County Hosp. Auth., 247 Ga. 86, 89, 274 S.E.2d 457, 460 (1981) (Hill, J., concurring) (concurring in order compelling pregnant woman to submit to cesarean section, but noting that: "[T] he power of a court to order a competent adult to surgery is exceedingly limited. Indeed, until this unique case arose, I would have thought such power to be nonexistent.").

58 See In re Torres, No. N-3968/88 (N.Y., Fam. Ct., Bronx County Oct. 7, 1988).

59 Id. at 6-7.

60 Bowers v. Hardwick, 478 U.S. 186, $191-92$ (1986) (quoting Palko v. Connecticut, 302 U.S. 319, 325-26 (1937)).

61 The fundamental nature of the right involved is also illustrated by Jed 
As a unanimous Court wrote in Whalen $v . R o e,{ }^{62}$ among the lifeshaping decisions the Court has found to be protected from government interference as part of the fundamental right to privacy are "matters relating to marriage, procreation, contraception, family relationships, and child rearing and education."63 The Supreme Court has held that "at the very heart" of the right to privacy lies "the decision whether to bear or beget a child." "64 Although courts have more often been confronted with attempts by the government to interfere with women's decisions to prevent or terminate pregnancies, ${ }^{65}$ equally protected by the Constitution is a woman's choice to give birth. ${ }^{66}$ Just as the government may not force a woman to bear an unwanted child by restricting women's use of contraceptives ${ }^{67}$ or access to abortion, ${ }^{68}$ the government may not prevent women from having children through involuntary sterilization ${ }^{69}$ or abortion. ${ }^{70}$ As with other fundamental rights, the government may not accomplish through indirect coercion what it may not do

Rubenfeld's recent conception of the right to privacy as "the right not to have the course of one's life dictated by the state." Rubenfeld, The Right of Privacy, 102 Harv.

L. REv. 737, 807 (1989).

62429 U.S. 589 (1977).

63 Id. at 600 n.26 (citing Paul v. Davis, 424 U.S. 693, 713 (1976)).

64 Carey v. Population Servs. Int'l, 431 U.S. 678, 685 (1977) (quoting Eisenstadt v. Baird, 405 U.S. 438,453 (1922)).

65 As the Court recognized, "[f]ew decisions are more personal and intimate, more properly private, or more basic to individual dignity and autonomy than a woman's decision . . . whether to end her pregnancy." Thornburgh v. College of Obstetricians \& Gynecologists, 476 U.S. 747, 772 (1986).

66 Thus, the Court held unconstitutional a requirement that school teachers take unpaid maternity leave for the last five months of a pregnancy. See Cleveland Bd. of Educ. v. LaFleur, 414 U.S. 632 (1974). Noting that "freedom of personal choice in matters of marriage and family life is one of the liberties protected by the Due Process Clause of the Fourteenth Amendment," the Court stated that "[b]y acting to penalize the pregnant teacher for deciding to bear a child, overly restrictive maternity leave regulations can constitute a heavy burden on the exercise of these protected freedoms." Id. at 639-40.

67 See Carey, 431 U.S. 678 (1977); Eisenstadt v. Baird, 405 U.S. 438 (1972); Griswold v. Connecticut, 381 U.S. 479 (1965).

68 See Thornburgh, 476 U.S. 747 (1986); City of Akron v. Akron Center for Reproductive Health, 462 U.S. 416 (1983); Roe, 410 U.S. 113 (1973).

69 See Skinner v. Oklahoma, 316 U.S. 535 (1942).

70 As Justice Stevens recognized, "if federal judges must allow the state to make the abortion decision, presumably the state is free to decide that a woman may never abort, may sometimes abort, or in the People's Republic of China, must always abort if her family is already too large." Thomburgh, 476 U.S. at 778 n.6 (Stevens, J., concurring) (emphasis in original). Even Solicitor General Kenneth Starr and former Solicitor General Charles Fried, in urging the Court to overrule Roe, conceded that the Constitution protects the right to be free from governmentally compelled abortions. See infra note - 
directly. ${ }^{71}$ Permitting a legal regime in which a host of special restrictions and penalties-not applied equally to all-are imposed on women based on their reproductive capacity severely interferes with a woman's decisions about childbirth.

Perhaps the most difficult context in which to argue against the constitutionality of special restrictions directed against women on the basis of pregnancy is the context in which such restrictions recently have been most threatened: the use of illegal substances by pregnant women. In contrast to more broadly defined legal obligations imposed on pregnant women, an added burden attached to the already illegal behavior of using controlled substances may not involve as great a risk of chilling socially or personally valuable behavior on the part of the pregnant woman. Society has already determined, independent of the harm to the fetus, that the behavior at issue should not occur, in part because it is harmful to the woman herself. The specificity of the restriction also may mitigate against problems created by changing notions of "proper" behavior during pregnancy. Moreover, the risks of harm to fetal development by drug use by pregnant women are high in comparison to the varied and uncertain risks associated with the unspecified constraints on behavior imposed by a general duty of care. Finally, the woman's state of addiction is likely to diminish the quality of her decisionmaking in general and the extent to which she is willing to alter her behavior to reflect the effects on fetal development.

Clearly, the Constitution's guarantee of privacy does not directly protect the right of any individual to engage in each of the countless activities that could be affected by a governmental assertion of fetal interests hostile to women's liberty. Yet women's fundamental right to privacy is implicated by any government intrusion that singles out pregnant women for disadvantageous treatment regarding a particular activity, whether or not the government could restrict or even

71 See, e.g., San Antonio Indep. School Dist. v. Rodriguez, 411 U.S. 1, 38 (1973) (strict scrutiny required if law has " 'deprived,' 'infringed,' or 'interfered' with the free exercise of some such fundamental personal right or liberty"). Thus, as the Court explained, the government is constitutionally barred not only from prohibiting the distribution of contraceptives but also from requiring that the distribution of contraceptives be only by licensed pharmacists or from prohibiting advertising about contraceptives. See Carey, 431 U.S. 678 . In the abortion context, the Court has held unconstitutional statutes that forced women to wait a specified period of time before obtaining an abortion, see Akron, 462 U.S. at $450-51$, that required abortion to be performed in hospitals, see id. at 431-33, and that imposed biased or "specific and intrusive" informed consent requirements, See Thornburgh, 476 U.S. at 759-63; Akron, 462 U.S. at 442. 
criminalize that same activity for all persons. Some commentators have argued that unless the particular activity at issue, such as riding in a car or smoking cigarettes or using cocaine, is itself entitled to fundamental constitutional protection, burdens placed uniquely on pregnant women's ability to engage in that behavior are subject only to rational basis review. ${ }^{72}$ This analysis ignores the critical fact that the constitutionally suspect governmental action that triggers heightened scrutiny is the imposition of additional burdens on women solely on the basis of their reproductive capacity. Although the state could-and in some cases does-ban the use by any person (including a pregnant woman) of a certain substance (such as cocaine, alcohol or cigarettes), prohibiting only pregnant women from using that substance is meant to control behavior only as it relates to procreation. ${ }^{73}$ The government's rationale underlying differential and disadvantageous treatment on the basis of pregnancy could be used to impose special restrictions of virtually unlimited scope on women's liberty, consequently treating pregnant women as less than full legal persons. A woman's autonomy in matters of childbearing is undeniably burdened by governmental attempts to deprive pregnant women of the power to make their own decisions and control their own lives during pregnancy to the same extent that all other people are permitted to do so.

For example, in accordance with its declaration that life begins at conception and in order to protect the safety of the fetus, the Missouri legislature might enact a law forbidding pregnant women-or all potentially pregnant women-to drive cars over 45 miles per hour on roads where others are permitted to drive 55 miles per hour. The

72 See, e.g., Note, Maternal Substance Abuse: The Need to Provide Legal Protection for the Felus, 60 S. CAL. L. REv. 1209, $1219-20$ (1987) (stating that "in the case of maternal substance abuse, the right which collides with the state's interest in the life and wellbeing of a fetus is the pregnant mother's right to use alcohol, tobacco and drugs for physical and psychic pleasure .... The issue ... is a pregnant woman's right to use alcohol, tobacco, and narcotics after she has decided not to obtain an abortion").

73 A recent Note in the Harvard Law Review made this point well:

The decisions in question here - what to eat or drink, when to go the doctor, whether to have sex, and so forth - have both procreative and nonprocreative aspect. Indeed, regulating such decisions for all people for example, banning all alcohol consumption - has no procreative significance. If states limit consumption only for pregnant women, however, they would be regulating the procreative aspect of the decision whether to drink. Such laws seek to control the incidents of procreation, infringing on a woman's power to make decisions about how she will live her life during her pregnancy.

Note, Maternal Rights and Fetal Wrongs: The Case Against the Criminalization of "Fetal Abuse," 101 HaRv. L. Rev. 995, 1000 (1988). 
Constitution does not guarantee a fundamental right to drive over 45 miles per hour, and the state could make it illegal for everyone to exceed that speed limit. Similarly, the government can and has made illegal the use of cocaine by any person, and a woman clearly is not immune from prosecution under such general laws simply because she is or may become pregnant. Yet a law that would impose a lower speed limit or greater penalty for cocaine use as a special burden only on pregnant women must be closely scrutinized to ensure that the additional penalty is necessary to promote a compelling governmental interest. Without such judicial review, women would be forced to live in fear that should they became pregnant, or simply choose to remain fertile, the government could impose extensive burdens on their freedom. Such interference with women's liberty may seem more justifiable as the risk of fetal harm increases. Concern about increased risk, however, is relevant only to whether the state's interest is compelling and the restriction necessary and not to the basic notion that special restrictions implicate a fundamental liberty interest and require strict scrutiny.

Given the physical realities of pregnancy, the recognition of hostile fetal interests implicates not only the woman's right to decisionmaking autonomy in matters of childbearing, but also a second aspect of the fundamental right to privacy: the right to bodily integrity. Many commentators on the nature of the fundamental right to privacy have concluded that a degree of control over one's own physical person is essential to any definition of the privacy right. ${ }^{74}$ Because the fetus is a physical part of a woman, allowing the government to asșert and enforce interests in the fetus adverse to the woman's interests would by definition seize control over a woman's physical person.

Because the principle of bodily integrity is so deeply embedded in our common law and constitutional traditions, the government has rarely attempted bodily intrusions analogous to those inherent in the assertion of fetal interests against pregnant women. In the few existing relevant cases, the Supreme Court has rejected such attempts. The Court has found, for example, that "the individual's dignitary interests in personal privacy and bodily integrity" would be

74 See, e.g., Gerety, Redefining Privacy, 12 HARv. C.R.-C.L. L. REv. 233, 266 (1977) (stating that "[a]ny plausible definition of privacy ... . whatever the sources of its normative commitments, must take the body as its first and most basic reference for control over personal identity"). 
violated by compelling a criminal defendant to submit to surgery in order to retrieve a bullet necessary for the state's prosecution. ${ }^{75}$

The constitutional dimensions of the bodily intrusion inherent in governmental recognition of fetal interests in a manner antagonistic to pregnant women's liberty are perhaps clearest in the cases in which courts have ordered women to submit against their will to cesarean sections to further perceived fetal interests, despite all the attendant risks of surgery including possible injury from the general anesthesia and infection from the incision. ${ }^{76}$ In addition to the Missouri case, a study reported in the New England Journal of Medicine found that courts in at least ten states and the District of Columbia have overridden the decisions of competent, adult, pregnant women and ordered them to deliver by cesarean section. ${ }^{77}$ In at least one

75 See Winston v. Lee, 470 U.S. 753, 761 (1985); see also Rochin v. California, 342 U.S. 165, 172 (1952) (overturning criminal conviction based on evidence obtained from "shocking" bodily invasion of forced stomach pumping).

76 Even former Solicitor General Charles Fried, in urging the Court to overrule Roe $v$. Wade during oral argument in Webster, conceded that a forced medical procedure would violate the fourteenth amendment's guarantee of liberty:

Justice O'Connor: Do you think the state has the right to, if in a future century we had a serious overpopulation problem, has a right to require women to have abortions after so many children?

$M r$. Fried: I surely do not. That would be a different matter.

Justice O'Connor: What do you rest that on?

$M r$. Fried: Because unlike abortion, which involves the purposeful termination of future life, that would involve not preventing an operation but violently taking hands on, laying hands on a woman and submitting her to an operation and a whole constellation -

Justice O'Connor: And you would rest that on substantive due process protection?

Mr. Fried: Absolutely.

Transcript of Oral Argument, supra note 14.

In a brief submitted to the Supreme Court in Hodgson v. Minnesota, Nos. 881125, 88-1309 (Oct. 1989) (to be argued Nov. 29, 1989) the current Solicitor General, Kenneth Starr, also recognized that an unwanted medical intrusion would violate the Constitution. Although still urging the Court to overrule Roe and hold that the government may prohibit women from obtaining abortions, the Solicitor General attempted to distinguish government action that would force women to have abortions. "By contrast, a state law mandating abortions would present a starkly different question. Our Nation's history and traditions establish that a competent adult may generally refuse unwanted medical intrusion. This right would, we believe, extend to an unwanted abortion." Brief for the United States as Amicus Curiae Supporting Respondents In No. 88-1125 And Supporting Cross-Petitioners in No. 88-1309, Hodgson, at 14 n.7. Both Fried and Starr failed to recognize the obvious: compelled pregnancy and childbirth-including six to twelve hours or more of grueling labor and delivery, or abdominal surgery in the one in four cases in which delivery is by cesarean section-also constitute the government "violently taking hands on, laying hands on a woman," counter to "our Nation's history and tradition."

77 See Kolder, Gallagher \& Parsons, supra note 47. 
such case, the woman physically resisted the surgery and was tied to the hospital bed while her husband was forcibly removed. ${ }^{78}$ In a second case, a woman who was very ill with cancer was ordered to undergo a cesarean section, despite the unanimous objections of the woman, her husband, her parents and her physicians, and despite the uncontroverted fact that it might hasten the woman's death. ${ }^{79}$ The fetus was not viable and did not survive; the woman herself died two days later. The District of Columbia Court of Appeals, which had refused to stay the order, issued an opinion subsequent to the woman's death in which it stated, "we well know that we may have shortened [her] life span," but concluded that the value of her remaining life was outweighed by the "slim" chance that the fetus might survive. ${ }^{80}$ The woman's death certificate listed the surgery as a contributing factor.

These wide-ranging special burdens ostensibly imposed in the name of fetal protection obviously are directed only against women, and only women suffer the resulting deep deprivations of liberty. ${ }^{81}$ By promoting governmental interests in improving fetal development through the means of exerting governmental control over women's decisions and actions regarding employment, medical treatment, diet and overall lifestyle choices, male-dominated governmental bodies echo the rationale behind laws that once barred women from equal protection in the paid labor force ${ }^{82}$ and political and civic

78 "Confronted with the doctor's intentions, the woman and her husband became irate. The husband was asked to leave, refused, and was forcedly removed from the hospital by seven security officers. The woman became combative and was placed in full leathers, a term that refers to leather wrist and ankle cuffs that are attached to the four corners of a bed to prevent the patient from moving. Despite her restraints, the woman continued to scream for help and bit through her intravenous tubing in an attempt to get free." Gallagher, Prenatal Invasions $\mathcal{E}^{\circ}$ Interventions: What's Wrong With Fetal Rights, 10 HARv. WoMEN's L.J. 9, 10 (1987) (quoting V. Kolder, Women's Health Law; A Feminist Perspective, 1-2 (Aug. 1985) (unpublished manuscript) (on file at the Harvard Women's Law Joumal).

79 See In re A.C., 533 A.2d 611 (D.C. 1987), vacated E reh'g en banc granted, 539 A.2d 203 (D.C. 1988).

80 See id. at 613-14, 617.

81 An additional cause for concern is that special restrictions are likely to be placed disproportionately on poor women and women of color. For example, a national survey that documented twenty-one cases in which court orders were sought to compel pregnant women to undergo medical treatment (fifteen cases involved cesarean sections, three cases involved hospital detentions, and the remaining three cases involved intrauterine transfusions), found that $81 \%$ of the women involved were black, Asian, or Hispanic. See Kolder, Gallagher \& Parsons, supra note 47, at $1192-93$.

82 See, e.g., Muller v. Oregon, 208 U.S. 412 (1908) (special restrictions placed on 
affairs. ${ }^{83}$ Then, as now, the law's professed concern was that certain actions by women-such as working above a specified maximum number of hours-would have "injurious effect upon the body," which was a proper focus of concern for the government because "as healthy mothers are essential to vigorous offspring, the physical wellbeing of women becomes an object of public interest and care in order to preserve the strength and vigor of the race."84 Thus, in addition to implicating women's fundamental privacy rights, special penalties imposed on pregnant women discriminate on the basis of gender and therefore must be supported by an " "exceedingly persuasive justification." "85

\section{Strict Scrutiny: Two Applications}

As is generally true of a law that interferes with an individual's fundamental rights, any action that places special burdens on women premised on women's childbearing capacity must be strictly scruti-

the number of hours women were permitted to work outside the home); Bradwell v. Oregon, 83 U.S. (16 Wall.) 130 (1872) (women excluded from the practice of law). 83 See, e.g., Hoyt v. Florida, 368 U.S. 57 (1961) (women exempted from participation in jury duty), overruled, Taylor v. Louisiana, 419 U.S. 522 (1975); Breedlove v. Suttles, 302 U.S. 277 (1937) (women who "chose" not to vote exempted from paying poll tax).

84 Muller, 208 U.S. at 421.

85 Mississippi Univ. for Women v. Hogan, 458 U.S. 718, 724 (1982) (quoting Kirchberg v. Feenstra, 450 U.S. 461 (1981)). For a more extensive discussion of the limitations imposed by the guarantee of equal protection on the governmental promotion of fetal interests, see Note, supra note 28 , at $620-25$.

The Court's decision in Geduldig v. Aiello, 417 U.S. 484 (1974), creates some doubt concerning the protection that the Supreme Court will afford women in this context by the guarantee of equal protection. The Court in Geduldig declaredbriefly in a footnote-that the exclusion of pregnant women from state disability insurance benefits did not discriminate against women by permissibly distinguished between pregnant women and nonpregnant persons. See id. at 496 n.20. Geduldig has been widely criticized by commentators, see, e.g., L. Tribe, AMERICAN Constitutional Law $\$ 15-29$, at 1578 (2d ed. 1988) (describing distinction as "so artificial as to approach the farcical"), and the Court's application of Geduldig to the Title VII context in General Elec. Co. v. Gilbert, 429 U.S. 125 (1976), was rejected by Congress through passage of the Pregnancy Discrimination Act of 1978, Pub. L. No. 95-555, 92 Stat. 2076 (codified at 42 U.S.C. 20003(k) (1982).

Whether or not Geduldig remains good law, it would not be dispositive here. In a subsequent decision, the Court, now with Chief Justice Rehnquist writing for the majority, adopted a limiting interpretation of Geduldig by distinguishing between the refusal in Geduldig to extend a "benefit that men cannot and do not receive" and the imposition of a "burden that men need not suffer." Nashville Gas Co. v. Satty, 434 U.S. 136 (1977). The imposition of special penalties and restrictions only on women on the basis of pregnancy falls squarely on the affirmative burden side, and can in no way be considered the failure to provide a benefit. See L. TRIBE, supra, § 15-29, at 1579 (describing distinction as "at best problematic"). 
nized. The constitutional bar to governmental intrusion in these protected areas is not absolute. Rather, courts evaluating such governmental action must carefully examine the interest being pursued by the government to determine whether it is compelling. Not only must the governmental interest be sufficiently compelling to justify the intrusion, the governmental act at issue must also actually further that compelling interest and must be narrowly tailored to do so.

An application of strict scrutiny to instances in which the government has already sought to promote fetal interests by controlling women's actions reveals that, though theoretically possible, no use of such coercive measures is likely to survive strict scrutiny. The governmental interest asserted to be compelling is the important goal of promoting healthy pregnancies and healthy babies. An infant born suffering from a physical injury that occurred during fetal development due to a pregnant woman's behavior will have to live with the hardships of that injury. ${ }^{86}$ The government undoubtedly has a strong interest in improving the health of our nation's infants, just as it does in safeguarding the health of all U.S. citizens. No one would dispute the desirability of that goal. The United States has a great deal of room for improvement in this area: its infant mortality rate places it a dismal eighteenth in the world. ${ }^{87}$

That the government's interest is an important one, however, does not ensure that it is sufficiently compelling to justify interference with a fundamental right. Although the Supreme Court has never articulated precise guidelines for determining whether a particular asserted interest is compelling, it is evident from the Court's

86 This interest is analytically distinct, for example, from a governmental interest in prohibiting abortion after viability or the interest asserted by Missouri through its sweeping declaration that life begins at conception. The Missouri declaration is aimed at creating "fetal personhood" under the law, including a fetal right-to-be-born. It does not reflect a concern for the future child, but a belief that the fertilized ovum is already a child and deserving of the same legal protection as a child, even at the expense of the pregnant woman.

87 See Children's Defense Fund, The Health of America's Children 12 (1989). The incidence of low birthweight in this country has not improved in this decade, and has actually increased among women of color. Id. at 6 . Low birthweight is closely tied to infant mortality: infants born weighing 2,500 grams ( 5.5 pounds) or less are almost 40 times more likely to die during their first four weeks of life than normal birthweight infants. See Hughes, Johnson, Rosenbaum \& Simons, The Health of America's Mothers and Children: Trends in Access to Care, 20 Clearinghouse Review 472 (1986). In addition to its interest in the social costs, the government also has a monetary interest at stake. By the year 2000 the government will spend 6 billion dollars annually on the care of low birthweight infants during their first year of life. See Health of American's Children, Maternal and Child Health Data Book (I989). 
jurisprudence that it the Court will not unquestionably accept a state's mere assertion that an interest is compelling. ${ }^{88}$ The Court has carefully evaluated even interests that appear to be compelling in the abstract to ascertain whether the interest outweighs in importance the protection of a particular right in a particular context. ${ }^{89}$ For example, among the important interests the Court has found to be insufficiently compelling in certain contexts to outweigh competing rights and interests are interests in protecting the victims of sexual abuse, ${ }^{90}$ protecting foreign diplomats in accordance with international law, ${ }^{91}$ redressing generalized societal racial discrimination, ${ }^{92}$ providing role models for minority students, ${ }^{93}$ and preserving the public order. ${ }^{94}$ So, too, an interest in improving infant health, while extremely weighty, is insufficiently compelling to justify allowing the government to control the actions of pregnant women in ways "essentially limitless in scope and duration"95 and unparal-

88 As the Court recently reaffirmed: "[T]he mere recitation of a benign, compensatory purpose is not an automatic shield which protects against any inquiry into the actual purposes underlying a statutory scheme." City of Richmond v. J.A. Croson Co., 109 S. Ct. 706 (1989) (quoting Weinberger v. Wiesenfeld, 420 U.S. 636, 648 (1975)). For a comprehensive discussion of compelling interests in the related context of abortion restrictions, see Dellinger \& Sperling, Abortion and the Supreme Court: The Retreat from Roe v. Wade, 138 U. PA. L. REv. 83 (1989).

89 The author used this argument in a brief submitted in Webster to oppose the recognition of a compelling interest in potential life from the moment of conception that is sufficient to outweigh a woman's fundamental right to choose to have an abortion. See Brief of Seventy-seven Organizations Committed to Women's Equality as Amici Curiae in Support of Appellees, Webster, 109 S. Ct. 3040 (1989).

90 See Coy v. Iowa, 108 S. Ct. 2798, 2802 (1988) (criminal defendant's sixth amendment rights "outweighed" state's interest in "protecting victims of sexual abuse").

91 See Boos v. Barry, 108 S. Ct. 1157, 1165 (1988) (though "as a general proposition" the government "has a vital national interest" in protecting foreign diplomats in accordance with international law, that interest is not "automatically ... compelling" when its assertion infringes upon first amendment rights); see also Korematsu v. United States, 323 U.S. 214, 244 (1944) (Jackson, J., dissenting) (arguing that courts may not "distort" the Constitution in order to approve all that the state may deem to be expedient and in the national interest when fundamental rights are at stake).

92 See City of Richmond v. J.A. Croson Co., 109 S. Ct. 706, 723 (1989) (governmental interest in redressing generalized societal discrimination deemed not to be sufficiently compelling to justify race-conscious remedies).

93 See id. (governmental interest in providing role models not sufficiently compelling to justify race-conscious remedies because it "could be used to 'justify" race-based decisionmaking essentially limitless in scope and duration" (citing Wygant v. Jackson Bd. of Educ., 476 U.S. 267, 286 (1986))).

${ }_{94}$ See Cohen v. California, 413 U.S. 15, 25 (1971) (governmental interest in preserving the public order not sufficiently weighty to justify restrictions on free expression because it is "inherently boundless").

95 Croson, 109 S. Ct. at 723. 
leled in our American system of law. ${ }^{96}$ The willingness of male-dominated legislatures and courts to inflict unique burdens on pregnant women not also imposed generally on the public is particularly suspect in light of our nation's "long and unfortunate history" 97 of unequal treatment of women on the basis of pregnancy.

Even assuming that the governmental interest being asserted was sufficiently compelling to support special restrictions on pregnant women's liberty, such measures are generally not necessary or narrowly tailored; moreover, they do not further at all the government's interest in the fetus and often prove to be counterproductive. The important goal of promoting healthy pregnancies and healthy babies is far better served by recognizing the commonalities of interest between pregnant women and the government in accomplishing this goal, rather than by artificially creating legal conflicts between pregnant women and the fetuses they carry.

This is true even in what is perhaps the most difficult context in which to argue against the constitutionality of special restrictions imposed on women on the basis of pregnancy: the use of already illegal substances by pregnant women. As discussed above, even if a particular activity is already illegal, any governmental action aimed at imposing additional burdens and penalties on the procreative aspect of that activity only when engaged in by pregnant or potentially pregnant women must be narrowly tailored to further a compelling governmental interest. ${ }^{98}$

Of course, substance abuse by pregnant women is a serious problem which can be detrimental to fetal development as well as to women's own health. Although the government has an important role to play in addressing this problem, directing special penalties against women for substance abuse during pregnancy simply is not effective. ${ }^{99}$ None of the specific coercive measures used to date can

96 While special governmental regulation of women's behavior would seek to protect the health an well-being of a person that will be born in the future, the law never imposes comparable burdens on all individuals to protect other people who are already born. See L. TRIBE, supra note 85, § 15-10, at 1354 ("'[T] he law nowhere forces men to devote their bodies and restructure their lives even in those tragic situations (such as organ transplants) where nothing less will permit their children to survive.").

97 Frontiero v. Richardson, 411 U.S. 677, 684 (1973).

98 See supra notes $69-70$ and accompanying text.

99 For an excellent analysis from a health policy perspective of the ineffectiveness of imposing special interest criminal penalties on substance abuse during pregnancy, see Note, Pregnancy Police: The Health Policy and Legal Implications of Punishing Pregnant Women for Harm to Their Feluses, 10 N.Y.U. Rev. L. \& Soc. Change 277, 292-309 (1987-88). 
survive close scrutiny. The remainder of this comment will examine two such attempts: the first criminal prosecution of a woman for allegedly "neglecting" her fetus though drug use and other behavior while pregnant in the case of People $v$. Stewart ${ }^{100}$ and a bill introduced in the Senate in July 1989, which is a narrower, more precise attempt to legislate special penalties against pregnant women who use controlled substances.

\section{The Prosecution of Pamela Rae Stewart}

Pamela Rae Stewart gave birth to her third child, a son, in November 1985. ${ }^{101} \mathrm{He}$ was born with severe brain damage and died six weeks later. More than nine months after losing her son, Ms. Stewart was arrested and prosecuted for allegedly causing his death through her actions during pregnancy, including her use of marijuana and amphetamines. Ms. Stewart suffered great harm during the five months the charges were pending: she spent six days in jail before she could make bail, and the most intimate details of her personal life became a staple for the national press. As one editorial observed, the media "held back nothing, not even the details of her last sex act before the baby was delivered." 102 Ultimately, the court dismissed the charges, finding that the prosecution was pursuant to a criminal statute that did not extend to Ms. Stewart's alleged behavior. Yet, the court expressly left open the constitutionality of possible future legislation that might provide the basis for similar prosecutions.

In prosecuting Ms. Stewart, the state not only cited her alleged use of drugs during pregnancy, but also claimed that Ms. Stewart contributed to her son's death by failing to obtain adequate medical care during pregnancy. Specifically, she was accused of waiting many hours before seeking medical help after she began bleeding vaginally; the prosecution claimed that this was contrary to express advice from her physician to seek immediate medical care if she began to hemorrhage. The prosecutor claimed further that Stewart's

100 No. M508197 (San Diego, Mun. Ct. Feb. 23, 1987).

101 Information about the Stewart case is taken largely from the following sources: Defendant's Memorandum of Points and Authorities in Support of Demurrer to Complaint Without Leave to Amend, People v. Stewart, No. M508197 (San Diego, Mun. Ct. Feb. 23, 1987); Defendant's Memorandum of Points and Authorities in Support of Motion to Dismiss, People v. Stewart; Brief Amici Curiae, People v. Stewart. For further discussion of the Stewart case and the ethical and policy issues it raises, see Johnsen, A New Threat to Pregnant Women's Autonomy, Hastings Center Report, at 33 (Aug. 1987).

102 Editorial, Drop the Charges Against Stewart, The Tribune, Nov. 11, 1986, at B6. 
physician told her not to engage in sexual intercourse with her husband, but she nevertheless did so. She was prosecuted under a statute that made it a crime for a parent to "willfully omit[ ], without lawful excuse, to furnish necessary clothing, food, shelter or medical attendance, or other remedial care for his or her child." 103

The statute used in the Stewart case thus was not narrowly tailored to the government's interest in promoting healthy babies. Rather, by requiring women "to furnish necessary clothing, food, shelter or medical attendance, or other remedial care" to their fetuses, or face criminal prosecution and incarceration, it would have forced women to live their lives as ideal incubators and to subordinate all other interests including the well-being of themselves and their families in order to minimize any risk of fetal harm. The government's interest could not possibly be so broad as to support this outcome; clearly, the government wants women to work as productive members of society, the economy and the family.

A broad and vague requirement as in this statute would also be entirely unworkable and ineffective. Complicated choices involving the weighing of competing interests and risks arise every day of a woman's pregnancy - choices between the fundamental demands of job, family, and health. In a dissent from a decision of the United States Court of Appeals for the Seventh Circuit upholding an employer's blanket exclusion of all fertile women from working with lead, Judge Richard Cudahy suggested some of the intricacies of those decisions and why the decisions should be the woman's to make:

What is the situation of the pregnant woman, unemployed or working for the minimum wage and unprotected by health insurance, in relation to her pregnant sister, exposed to an indeterminate lead risk but well-fed, housed and doctored? Whose fetus is at greater risk? ... Whose decision is this to make ${ }^{104}$

Great uncertainties exist about what is desirable behavior for pregnant women. The conventional wisdom has altered dramatically over time, along with advances in knowledge and changes in societal attitudes about the extent to which women should be confined and defined by their role as childbearers. Moreover, because numerous factors contribute to fetal development, physicians and courts cannot predict with much reliability what effect a woman's actions will have

103 Cal. Penal Code $\$ 270$ (West Supp. 1986).

104 International Union v. Johnson Controls, 886 F.2d 871 (7th Cir. 1989) (en banc) (Cudahy, J., dissenting). 
on her fetus' development. Nor can the courts usually determine after a child's birth what particular action by the pregnant woman may have caused a particular infirmity.

To promote its interest in healthy babies, the government can pursue one of two very divergent approaches. The first approach, taken by the prosecutor in the Stewart case, employs means that are hostile to and create conflicts with women's interests and constitutional rights. The facts of the Stewart case dramatically illustrate, why the threat of criminal prosecution typically is ineffective and even counterproductive to improving the health of babies and pregnant women. Ms. Stewart was very poor; while pregnant with her third child, she lived with and cared for her husband and two small daughters, first in a single hotel room and then in a mobile home they shared with her mother-in-law. Ms. Stewart may have been a battered woman; the police were called ten to fifteen times over one year to respond to violence directed at Ms. Stewart and her motherin-law by Mr. Stewart. ${ }^{105}$ Ms. Stewart's son's injuries may have been caused by her loss of blood during delivery, which was due to her having a dangerous complication known as placenta previa, which can be life-threatening for the pregnant woman. Although her prosecution was based on her alleged failure to call for immediate medical help when she began bleeding, on two prior occasions Ms. Stewart had called her physician when she noticed she was bleeding; she had been told both times that "everything was fine."106

Yet there exists an alternative approach that is less restrictive as well as more effective than the creation of legal conflicts between pregnant women and the fetuses they bear. The government's interest in improving the health of newborns is entirely consistent with the interests of pregnant women and can be pursued by means that coincide with women's interests. A woman who has chosen to bear a child obviously has a great interest in giving birth to a healthy baby. Pregnant women typically will go to great lengths and risk significant harm to their own health in the interests of their future child's wellbeing. The typical problem for poor women like Ms. Stewart is not a lack of desire, but a lack of the resources necessary to improve the outcomes of their pregnancies., Fetal well-being is tied directly to the physical well-being of women during pregnancy. Clearly the principal means to promote the birth of healthy babies is to promote

105 See Neighbors Cite Mother's Troubled Past, Daily Californian, at la; The Ordeal of Pamela Rae Stewart, Ms. July/Aug. 1987, at 92, 94.

106 Woman Charged in Fetal Neglect Did Not Abuse Drugs, Husband Says, San Diego Union, Sept. 30, 1986, at Bl. 
healthy pregnancies by making available to all women good prenatal care as well as education about what constitutes good prenatal care. One-third of all women giving birth in 1985 did not receive adequate prenatal care. Statistics among black women are even worse: half did not receive proper medical attention before their babies were born. ${ }^{107}$ Infants of women who did not receive adequate prenatal care are more than three times as likely to die within the first year of birth. ${ }^{108}$ Low birthweight is largely preventable through high quality prenatal care, and also through good health care before pregnancy. A 1985 study by the Institute of Medicine of the National Academy of Sciences identifies women on welfare with less than a high school education as being at "high risk" of giving birth to a low birthweight infant with a higher risk of infant mortality and other health problems; the report concluded that "every additional dollar spent for prenatal care within the target group would save $\$ 3.38$ in the total cost of caring for low birthweight infants requiring expensive medical care." 109

\section{The Wilson Bill}

Since the Court decided Webster, three states have enacted statutes specifically imposing special penalties on women who use controlled substances during pregnancy, ${ }^{110}$ and in July 1989, Senator Peter Wilson introduced in the United States Senate a bill entitled the "Child Abuse During Pregnancy Prevention Act of 1989" designed to encourage the states to enact such legislation. ${ }^{111}$ In order to be eligible for a grant to establish a model project on pregnant women and substance abuse under the bill, a state must certify that it is a crime in that state for a woman to give birth to "an infant who is addicted or otherwise injured or impaired by the substance abuse of its mother during pregnancy." The state must impose a penalty of three years of incarceration in a custodial rehabilitation

107 See Children's Defense fund, The Health of America's Children 4 (1989).

108 See Hughes, Johnson, Rosenbaum \& Simons, The Health of America's Mothers and Children: Trends in Access for Care, 20 Clearinghouse Review 473 (1986).

109 National. ACademy of Sciences Instrtute of Medicine: Committee to Study the Prevention of Low Birthweight, Preventing Low Birthweight 1-4, 7 8, 20, 31 (1985).

110 See supra note 52.

111 S. 1444 101th Cong., 1st Sess. (1989) [hereinafter The Wilson Bill]. Many, if not all, of the recent prosecutions of women for allegedly causing fetal harm through drug use are constitutionally suspect because the prosecutions were pursuant to statutes that clearly were not enacted for that purpose. 
center for any woman convicted of this crime. The Wilson bill is a useful example on which to focus in order to examine the constitutionality of such legislation.

Interestingly, organizations from both sides of the abortion issue-from the National Abortion Rights Action League and Planned Parenthood to the National Right to Life Committee and the U.S. Catholic Conference-oppose the use of special punitive measures specifically aimed at women who use illegal drugs during pregnancy. This can be explained by the difference in the governmental interests behind restrictions on women's choice of abortion and penalties directed at pregnant women's use of controlled substances. While abortion restrictions are aimed at legislating a particular moral view of the fetus, the government's interest in preventing pregnant women from using controlled substances is aimed at improving the health of babies that will be born, and there is agreement among a broad spectrum of organizations that special punitive measures against pregnant women do not accomplish this latter goal.

The stated purpose of the Wilson bill is to prevent substance abuse by pregnant women, through outreach, intervention, and mandatory rehabilitation, in order to reduce the incidence of births of infants who are addicted or otherwise injured by their mother's substance abuse during pregnancy. The bill finds that 375,000 infants are born each year to women who engage in substance abuse during pregnancy, which accounts for eleven percent of all births. ${ }^{12}$ The bill describes the harm suffered by children as a result as including "severe and lasting or even irreversible physical, mental, and emotional damage to the child, including low birthweight, prematurity, congenital deformities, risk of child abuse, and death." The bill estimates that the annual cost of providing initial care to infants born suffering these harms is over thirteen billion dollars. ${ }^{13}$

While there is broad-based, vigorous opposition to the Wilson bill's specific substantive provisions, its recognition of the problems associated with substance abuse by pregnant women is relatively noncontroversial. ${ }^{114}$ Yet the government's interest in improving

$112 I d$. at $\S 2(\mathrm{a})(3)$.

113 Id. at $\$ 2$ (a)(4).

114 Dr. Ira J. Chasnoff, the president of the National Association of Perinatal Addiction Research and Education, one of the nation's leading experts on the effects on fetal development of substance abuse by pregnant women, testified before Congress on the Wilson bill and largely confirmed its findings as to the harmful effects of substance abuse. See Testimony of Dr. Ira J. Chasnoff, before the U.S. Senate Committee on Governmental Affairs, July 31, 1989. Yet Dr. Chasnoff is also one of the most vocal opponents of addressing the problem with punitive measures 
infant health does not rise to the level of a compelling interest supporting the imposition of special penalties, including incarceration and prosecution for murder, on substance abuse by pregnant women. Moreover, the existence of a compelling interest would not end the court's inquiry. The government action must also be effective and narrowly tailored to further the compelling interest.

Significantly, the Wilson bill, like the prosecution in the Stewart case, would restrict more than pregnant women's use of illegal substances. The Wilson bill includes in its definition of "substance abuse" the "excessive or injurious ingestion of legal substances, including beverage alcohol."115 Similarly, in ordering the incarceration of a woman for the duration of her pregnancy solely to prevent her from using cocaine, a Washington, D.C. judge indicated that he would consider jailing a woman to prevent her from drinking alcohol or smoking cigarettes. ${ }^{116}$ Certainly, the harms to fetal development through the ingestion by pregnant women of other substances, such as alcohol and cigarettes, make difficult a principled distinction, which highlights the problem with the government ever imposing special penalties on women in order to control their actions during pregnancy.

Measures such as the Wilson bill do not even meet the minimum threshold of furthering the asserted governmental interest. If the interest at issue is to decrease the harmful effects to fetal development of substance abuse by pregnant women, any effective strategy for dealing with the problem must increase women's ability to overcome their addictions. Coercive measures such as the Wilson bill have precisely the opposite effect and would exacerbate the problem. Threatening women with special penalties such as incarceration, in the form of three years of mandatory residential treatment, for using illegal drugs during pregnancy would not deter their use of drugs. ${ }^{17}$ It would, however, discourage women from seeking treatment and thereby making their addiction known. Fear of prosecution will also deter substance-dependent women from seeking any prenatal care at all, which is particularly harmful to fetal development because such women already constitute a high risk group in need of closely moni-

such as those contained in the Wilson bill. Dr. Chasnoff and groups like NARAL and the NRLC are united in their opposition to approaches such as the Wilson bill because they are simply ineffective.

115 The Wilson Bill, $\$ 3$ (a)(1).

116 See United States v. Vaughn, 117 Daily Wash. L. Rep. 441 (D.C. Super. Ct. Mar. 7, 1989).

117 The Wilson Bill, § 3 (c)(1)(c)(5). 
tored prenatal care. Women might even refuse to seek medical care at the time of delivery, due to the Wilson bill's requirement that health care providers report to the authorities the birth of "substance abused" infants; ${ }^{18}$ this would result in addicted babies being born under dangerous conditions without any medical attention.

The most intrusive means of pursuing the government's interest-putting substance-dependent women in prison in order to protect their fetuses-is also the least effective, and indeed counterproductive, because it is likely to increase the harm to fetal development. Prisons are notoriously unsafe and unhealthy for pregnant women and their fetuses. One two-and-a-half year study of three state prisons in California found that all three were far below the minimum standards set by the American College of Obstetricians and Gynecologists. ${ }^{19}$ The study also found that more than a third of the pregnancies resulted in late-term miscarriages, a rate more than twice that in the community. In one prison, only twenty-one percent of the pregnancies among inmates ended in live births. ${ }^{120}$

Finally, the government may not use the means of promoting its interest that is the most intrusive of women's liberty-imprisonment and mandatory residential treatment-when there exists a clearly less restrictive alternative of making voluntary treatment programs available for all pregnant women who desire help. In fact, voluntary treatment programs are not available for the majority of pregnant women who desire treatment. Many drug treatment programs routinely turn away pregnant women, partly due to fear of potential legal liability in cases of miscarriage or fetal abnormality. The wait for admission into a program is often longer than the remainder of the woman's pregnancy. Even in New York City, a survey of the treatment programs revealed that eighty-seven percent admitted that they would not treat pregnant women on Medicaid who were addicted to cocaine. ${ }^{121}$ The overwhelming majority of treatment

$118 I d . \S 3$ (c)(1)(c)(3).

119 See Lacroix, Birth of a Bad Idea; Jailing Mothers for Drug Abuse, The Nation, at 585-88 (1989).

120 See id. One report of three lawsuits against prison officials by pregnant inmates described the inmates' complaints as follows: "under normal circumstances, pregnant women in U.S. jails and prisons get little exercise or fresh air, eat poorly, and are crowded into unsanitary cells. In the worst of circumstances, they say, pregnant prisoners are locked in stripped-down isolation cells, given drugs dangerous to their unborn children, or shackled during labor and delivery." Stein \&c Mistiaen, Pregnant in Prison, The Progressive (Feb. 1988).[NOT EDITED]

121 See Testimony of Dr. Wendy Chavkin, before the House Select Committee on Children, Youth and Families, Apr. 27, 1989. 
programs that will admit pregnant women do not provide child care for the women's other children; a 1988 study by the Association of Junior Leagues found that the primary barrier for women in obtaining treatment was the lack of child care. ${ }^{122}$

Rather than creating constitutional and practical problems by attempting to treat the fetus as a legal entity separate from the pregnant woman of whom it is a physical part, and then asserting interests in conflict with the rights of the pregnant woman, the government should continue to recognize a pregnant woman as a single legal entity and help her to further her own strong interest in giving birth to a healthy baby. As a matter of good public policy, the government should choose this latter path; as a matter of constitutional limitations, the government must do so. 
